\title{
Mixed Signals
}




\section{Also by Kathryn Sikkink:}

Ideas and Institutions: Developmentalism in Brazil and Argentina (1 $99 \mathrm{I}$ )

Activists beyond Borders: Advocacy Networks in International Politics (coauthor, 1998)

The Power of Human Rights: International Norms and Domestic Change (coeditor, 1999)

Restructuring World Politics: Transnational Social Movements, Networks, and Norms (coeditor, 2002) 


\section{Mixed Signals}

mon

U.S. Human Rights Policy and Latin America

\section{Kathrin SikKINk}

A CENTURY FOUNDATION BOOK

Cornell University Press

Ithaca and London 
The Century Foundation

The Century Foundation, formerly the Twentieth Century Fund, sponsors and supervises timely analyses of economic policy, foreign affairs, and domestic political issues. Not-for-profit and nonpartisan, it was founded in 1919 and endowed by Edward A. Filene.

Board of Trustees of The Century Foundation

H. Brandt Ayers

Richard C. Leone

Peter A. A. Berle

Jessica Tuchman Mathews

Alan Brinkley, Chairman

Joseph A. Califano, Jr.

Alicia H. Munnell

Alexander Morgan Capron

Hodding Carter III

Edward E. David, Jr.

P. Michael Pitfield

John Podesta

Richard Ravitch

Brewster C. Denny

Christopher Edley, Jr.

Alan Sagner

Arthur M. Schlesinger, Jr.

Harvey I. Sloane, M.D.

Charles V. Hamilton

Theodore C. Sorensen

Matina S. Horner

Lewis B. Kaden

Kathleen M. Sullivan

James A. Leach

Shirley Williams

William Julius Wilson

Richard C. Leone, President

Copyright (C) 2004 by The Century Foundation, Inc.

All rights reserved. Except for brief quotations in a review, this book, or parts thereof, must not be reproduced in any form without permission in writing from the publisher. For information, address Cornell University Press, Sage House, 5 I 2 East State Street, Ithaca, New York 14850.

First published 2004 by Cornell University Press

First printing, Cornell Paperbacks, 2007

Printed in the United States of America

Library of Congress Cataloging-in-Publication Data

Sikkink, Kathryn, I $955^{-}$.

Mixed messages : U.S. human rights policy and Latin America /

Kathryn Sikkink.

p. cm.

Includes bibliographical references and index.

ISBN 978-0-8014-4270-4 (cloth : alk. paper)

ISBN 978-0-8014-7419-4 (pbk. : alk. paper)

I. Human rights-Latin America. 2. Civil rights-Latin America.

3. Democracy-Latin America. 4. Latin America-Relations-

United States. 5. United States-Relations - Latin America. I. Title.

$\mathrm{JC}_{599 . \mathrm{L}_{3} \mathrm{~S}_{55} 2004}$

$323^{\prime} .098-\mathrm{dc} 22$

2004007 I 59

Cornell University Press strives to use environmentally responsible suppliers and materials to the fullest extent possible in the publishing of its books.

Such materials include vegetable-based, low-VOC inks and acid-free papers that are recycled, totally chlorine-free, or partly composed of nonwood fibers. For further information, visit our website at www.cornellpress.cornell.edu.

Cloth printing $\quad$ I $09 \begin{array}{lllllllll}9 & 8 & 7 & 6 & 5 & 4 & 3 & 2 & \text { I }\end{array}$

Paperback printing $\quad$ I $09 \begin{array}{lllllllll}9 & 8 & 7 & 6 & 5 & 4 & 3 & 2 & \text { I }\end{array}$ 
For my sons, Daniel and Matthew Sikkink Johnson, with love 
